University of Montana

ScholarWorks at University of Montana

\title{
Influence of Alternate Host Densities on Brown-Headed Cowbird Parasitism Rates in Black-Capped Vireos
}

D. R. Barber

Thomas E. Martin

University of Montana - Missoula, tom.martin@umontana.edu

Follow this and additional works at: https://scholarworks.umt.edu/wildbio_pubs

Part of the Life Sciences Commons

Let us know how access to this document benefits you.

\section{Recommended Citation}

Barber, D. R. and Martin, Thomas E., "Influence of Alternate Host Densities on Brown-Headed Cowbird Parasitism Rates in Black-Capped Vireos" (1997). Wildlife Biology Faculty Publications. 44.

https://scholarworks.umt.edu/wildbio_pubs/44

This Article is brought to you for free and open access by the Wildlife Biology at ScholarWorks at University of Montana. It has been accepted for inclusion in Wildlife Biology Faculty Publications by an authorized administrator of ScholarWorks at University of Montana. For more information, please contact scholarworks@mso.umt.edu. 


\title{
INFLUENCE OF ALTERNATE HOST DENSITIES ON BROWN-HEADED COWBIRD PARASITISM RATES IN BLACK-CAPPED VIREOS ${ }^{1}$
}

\author{
DAVID R. BARBER ${ }^{2}$ \\ Arkansas Cooperative Fish and Wildlife Research Unit, University of Arkansas, Fayetteville, AR 72701, \\ email: natcons@avonpark.macdill.af.mil \\ Thomas E. Martin ${ }^{3}$ \\ U.S. Biological Resources Division, Montana Cooperative Wildlife Research Unit, Avian Studies Program, \\ University of Montana, Missoula, MT 59812,email: tmartin@selway.umt.edu
}

\begin{abstract}
Brown-headed Cowbird (Molothrus ater) parasitism is thought to be partly influenced by density of the host species, although tests of host density are relatively rare. We examined parasitism rates relative to the density of individual host species and densities of coexisting host species. We monitored 392 nests among coexisting host species and measured their densities among six habitats on Fort Hood Military Reservation, Texas during 1991-1992 to test the hypothesis that coexisting species affect parasitism rates in the endangered Black-capped Vireo (Vireo atricapillus). Black-capped Vireos and White-eyed Vireos (V. griseus) suffered three to four times higher cowbird parasitism than Northern Cardinals (Cardinalis cardinalis) or Painted Buntings (Passerina ciris). After controlling for removal of female cowbirds, which has been conducted on the study site since 1988, parasitism rates in Black-capped Vireos were positively correlated with cumulative host density in general, and Northern Cardinal density in particular. Only density of Northern Cardinals explained a significant amount of variation in parasitism rates in Black-capped Vireos among sites. We suggest that cowbirds may be attracted to conspicuous species, such as cardinals, and that high densities of such species may negatively affect coexisting species by increasing probabilities of being parasitized. Vireo nests were characterized by less nest concealment, greater canopy cover, and more stems than other species. However, nest site and vegetation characteristics did not differ between parasitized and unparasitized nests for any species, suggesting habitat was unimportant to parasitism.
\end{abstract}

Key words: brood parasitism, Black-capped Vireo, Brown-headed Cowbird, indirect effects, Vireo atricapillus, Molothrus ater.

\section{INTRODUCTION}

Brown-headed Cowbirds (Molothrus ater) lay their eggs in nests of other species and generally reduce the reproductive success of their hosts (Rothstein 1975, Payne 1977, May and Robinson 1985). Cowbird parasitism has been cited as a major cause for population declines in two endangered species: Kirtland's Warbler (Dendroica kirtlandii) (Mayfield 1977) and Black-capped Vireo (Vireo atricapillus) (Gryzbowski et al. 1986, U.S. Fish and Wildlife Service 1991), two endangered subspecies, Least Bell's Vireo ( $V$. bellii pusillus) (Goldwasser et al. 1980, Franzreb 1989) and Southwestern Willow Flycatcher (Empidonax trailii extimus) (Unitt 1987, Brown

\footnotetext{
${ }^{1}$ Received 8 December 1995. Accepted 24 March 1997.

${ }^{2}$ Current address: The Nature Conservancy, $225 \mathrm{E}$. Stuart Avenue, Lake Wales, FL 33853.

${ }^{3}$ Corresponding author.
}

1988), as well as common species such as Dickcissel (Spiza americana) (Fretwell 1977). Moreover, cowbird parasitism may be the cause of recent increases in the rate of population declines of passerines in the midwest (Robinson 1992).

Brown-headed Cowbirds are known to parasitize over 200 species of birds (Friedman 1963, Friedman and Kiff 1985). Despite the cowbird's generalist nature, most studies have focused on parasitism relative to densities of individual host species (Graber 1961, Fretwell 1977; see citations above) and ignored possible effects of coexisting species on parasitism rates of each other (but see Clark and Robertson 1979). Species can affect each other both directly and indirectly. Indirect effects may be subtle and difficult to detect. Most work on indirect effects has focused on predator-prey interactions. For example, coexisting prey species can increase predation on each other when they share a predator that re- 
sponds to their cumulative densities (Holt 1977, Schmitt 1987, Martin 1988, 1996). Similar interactions have been suggested for brood parasites and their hosts (Martin 1992), but this has not been rigorously tested.

Circumstantial evidence suggests that cowbirds may respond to cumulative densities of coexisting host species. Lowther and Johnston (1977) found higher densities of cowbirds where bird (i.e., potential host) density was greatest. Cowbird abundance also was highly correlated with host density in Illinois (Robinson and Wilcove 1994). If cowbirds respond to cumulative host densities, coexistence of host species may increase the probability of parasitism on each other (Martin 1992). On the other hand, Yellow Warblers (D. petechia) had lower parasitism rates in areas with high densities of Red-winged Blackbirds (Agelaius phoeniceus) than in areas with low densities of blackbirds (Clark and Robertson 1979) because the aggressive and colonial nature of blackbirds may make surreptitious entry by cowbirds difficult. For less aggressive and noncolonial species, cowbirds might be attracted to areas with more hosts because of the increased opportunities for parasitism, and cowbirds may be particularly attracted to areas with highly conspicuous hosts. Such responses could lead to negative (detrimental) effects of coexisting species on each other (Martin 1992). The potential existence of such effects are important to examine because they can provide insight into cowbird host searching behavior and may be important to the management of endangered species threatened with cowbird parasitism; abundance or types of coexisting hosts may affect parasitism probability of the endangered species.

Alternatively, probability of parasitism may be more strongly influenced by habitat characteristics near the nest sites than by coexisting hosts. Female cowbirds often perch on the top of snags and may use these perches to observe host behavior and locate nests. In an open jack-pine habitat, Anderson and Storer (1976) found that Kirtland's Warbler nests with snags nearby were more likely to be parasitized. Moreover, Freeman et al. (1990) found that cowbirds were more efficient at finding active nests in marshes with high densities of trees on the perimeter. The same pattern also was found for European Cuckoos (Cuculus canorus) parasitizing Rufous Warbler (Cercotrichas galactotes) nests (Alvarez 1993). Thus we might expect host spe- cies in open habitats with more trees and snags surrounding their nests to have higher parasitism rates. For species threatened with cowbird parasitism, habitat alteration, such as snag removal, may be a successful management tool.

We tested these alternative hypotheses to determine if host density and habitat structure around the nest affect parasitism rates in Black-capped Vireos on Fort Hood, Texas. Black-capped Vireos are ideally suited for such a study because they inhabit early successional scrub habitat. This patchily distributed habitat allowed us to study how variation in cumulative and alternative host densities affect cowbird parasitism rates in Black-capped Vireos among habitat patches.

\section{METHODS}

\section{STUDY AREA}

This study was conducted on Fort Hood Military Reservation, in Bell and Coryell counties in central Texas. Fort Hood is on the eastern edge of the Edward's plateau and is dominated by rolling hills and steep sloped ridges of remnant plateau (Tazik et al. 1990). Vegetation is typical of the Edward's Plateau and is dominated by ashe juniper (Juniperus ashei), shin oak (Quercus sinuata), live oak ( $Q$. fusiformis), Texas oak, $(Q$. texana), flameleaf sumac (Rhus lanceolata), skunkbush sumac ( $R$. aromatica), and Eastern redbud (Cercis canadensis).

\section{NESTING}

Black-capped Vireos inhabit early successional scrub habitat, which becomes suitable for nesting 3-5 years after burning, and remains suitable for 20-30 years thereafter (Graber 1961, Marshall et al. 1985). Early successional scrub habitat on Fort Hood is patchily distributed with areas of juniper forest or grassland separating suitable nesting area. Six habitat areas were used during the study $(\overline{\mathbf{x}}=46.1$ ha). Four habitat areas were searched for nests in 1991: Area 2 Top (31.5 ha), Area 2 Slope (26.0 ha), Red Bluff (40.5 ha), and West Fort Hood (106.3 ha). Two additional areas were searched in 1992: Manning Mountain (19.5 ha) and Brown's Creek (53.0 ha). Nest searches for all ground and shrub nesting species were conducted at each site every 2-3 days from 1 April to 15 July in both years. Once found, nests were monitored every 2-3 days for cowbird parasitism and to determine nest fate. 
Nests were considered parasitized by Brownheaded Cowbirds when one or more cowbird eggs or nestlings were found in a nest. Cowbird eggs were subsequently removed from Blackcapped Vireo nests as part of the management strategy, but not from nests of other species. There were no cases of nests being parasitized again after removal of cowbird eggs. None of the species were classified as rejectors (Rothstein 1975), so parasitism rate was calculated as the percentage of nests of each species that were parasitized.

\section{COWBIRD REMOVAL}

Cowbirds have been trapped and removed since 1988 on Fort Hood (Tazik and Cornelius 1990). Cowbird traps have been active April-July in all study sites since 1989 . One to two traps were placed in or near sites with several pairs of vireos. In 1992, trapping was not conducted at three of the six sites. Traps were checked every 1-3 days. Females were removed from the trap and euthanized; males were banded and released when time permitted, otherwise they were euthanized (Hayden and Tazik 1991). Rate of female removal was calculated as the number of females caught per day.

\section{HOST DENSITY}

Host densities were measured using a modified fixed-radius point count method (Hutto et al. 1986). Six to thirteen census points, with $100-\mathrm{m}$ intervals between points, were established in each habitat patch. Census points were laid out either in a grid or a transect depending on shape of the habitat patch. Number of points varied due to size of habitat patch. Censuses were conducted between $06: 00$ and 10:00 by a single observer in both years. At each point, we counted for $10 \mathrm{~min}$ the number of birds of each species detected within a $25 \mathrm{~m}$ radius circle. Each site was censused four times per season. Four sites were censused in 1991 and six in 1992. Cumulative host density and density of individual species were calculated as the number of individuals detected per point.

\section{NEST MEASUREMENTS}

For each active nest we recorded (1) nest height, (2) nest substrate, (3) orientation of nest with respect to central stem of nest substrate, (4) distance of nest from main stem, (5) percent canopy cover (measured as the amount of canopy cover above the nest of a $1 \mathrm{~m}^{2}$ area centered on the nest), (6) percent overhead cover (estimated as percent of the nest that was concealed from $15 \mathrm{~cm}$ above the nest), and (7) percent side cover (measured as percent of the nest concealed from $1 \mathrm{~m}$ away at nest height in each cardinal direction).

\section{VEGETATION MEASUREMENTS}

Vegetation was sampled in a 5-m radius circular plot $(0.008 \mathrm{ha})$ centered on the nest. Number of live stems of each species were counted and placed in each of four size classes: $0-2,2-6$, $6-10$, and $>10 \mathrm{~cm}$. Stems larger than $10 \mathrm{~cm}$ were counted within a $10-\mathrm{m}$ radius circular plot ( $0.03 \mathrm{ha}$ ) centered on the nest during 1992 only. Vegetation also was sampled at census points and at two points $50 \mathrm{~m}$ from each census point in opposite directions.

\section{STATISTICAL ANALYSES}

We tested whether parasitism rates differed between years, among species, and with species density. Parasitism rates were compared between years and among species using $G$-tests. Because parasitism rates were likely to be affected by cowbird removal, linear regression was used to test for a relationship between parasitism rate in Black-capped Vireos and rate of female cowbird removal at each site in 1991-1992. Because nest site characteristics did not differ between Black-capped and White-eyed Vireos (V. griseus) (Barber, unpubl. data), we also used linear regression to test for a relationship between parasitism rate in all vireos and rate of female cowbird removal. Residuals from these regressions represent relative parasitism rates with the effects of female cowbird removal removed. Residuals then were plotted against cumulative host density and density of individual species to look for a relationship between host densities and parasitism rates in vireos. Pearson partial correlation $\left(r_{\mathrm{p}}\right)$ was used to test for a relationship between (1) cowbird parasitism and cumulative host density and (2) cowbird parasitism and density of individual species, while controlling for removal of female cowbirds.

We tested whether cumulative host density and species density differed between years and among sites. Mann-Whitney $U$-tests were used to test for differences in cumulative host and species density between years for each plot. Kruskal-Wallis tests were used to examine dif- 


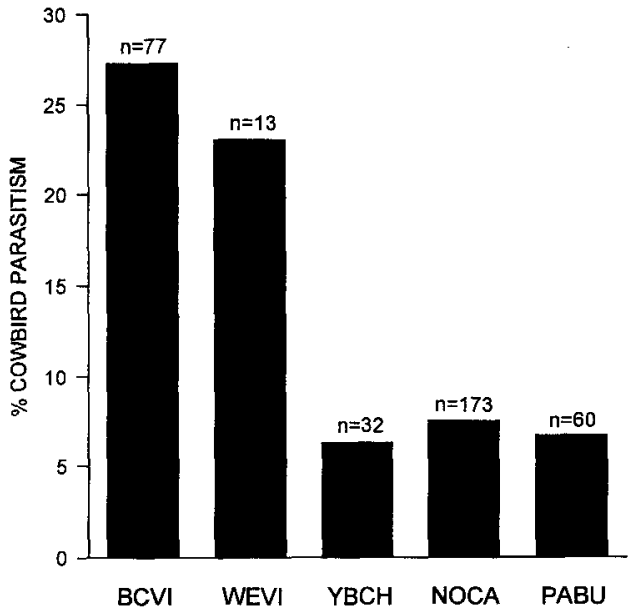

FIGURE 1. Percentage of nests parasitized by Brown-headed Cowbirds for Black-capped Vireo (BCVI), White-eyed Vireo (WEVI), Yellow-breasted Chat (YBCH), Northern Cardinal (NOCA), and Painted Bunting (PABU) on Fort Hood, Texas from 1991 to 1992. Numbers above columns are sample sizes of nests used for calculating parasitism rate.

ferences in cumulative host densities and species densities among sites.

We used univariate analysis of variance (ANOVA) and Duncan's multiple range test (SAS 1985) to test for differences in nest and vegetation characteristics among species. We also used ANOVA to test for differences in nest and vegetation characteristics between parasitized and unparasitized nests within species. Measurements of cover and stem count data were not normally distributed. Therefore, cover data were arcsine transformed and stem count data were square root transformed.

\section{RESULTS}

\section{NESTING}

A total of 392 nests of 11 species was found in 1991 and 1992. The five most common species and the number of nests $(n)$ found were: Black-capped Vireo (77), White-eyed Vireo (22), Yellow-breasted Chat (Icteria virens) (32), Northern Cardinal (Cardinalis cardinalis) (173), and Painted Bunting (Passerina ciris) (60).

\section{COWBIRD PARASITISM}

Cowbird parasitism did not differ between years for any species: Black-capped Vireos $\left(G_{1}=\right.$ $0.52, P=0.47)$, White-eyed Vireos $\left(G_{1}=1.83\right.$, $P=0.17)$, cardinals $\left(G_{1}=1.88, P=0.17\right)$,
TABLE 1. Cowbird parasitism rates on Black-capped Vireo nests among six study sites on Fort Hood, 19911992.

\begin{tabular}{lc}
\hline \hline \multicolumn{1}{c}{ Study site } & Parasitism rate (no. of nests) \\
\hline Area 2 top & $0.0(16)$ \\
Area 2 slope & $27.3(11)$ \\
West Fort Hood & $37.0(27)$ \\
Brown's Creek & $58.3(12)$ \\
Manning Mountain & $37.5(8)$ \\
Total parasitism rate & $29.9(77)$ \\
\hline
\end{tabular}

buntings $\left(G_{1}=0.62, P=0.43\right)$, and chats $\left(G_{1}\right.$ $=3.48, P=0.06$ ), so years were combined. Black-capped Vireos suffered approximately four times higher parasitism rates $(29.9 \%)$, and White-eyed Vireos three times higher parasitism rates $(23.1 \%)$, than chats $(6.3 \%)$, buntings $(6.7 \%)$, or cardinals $(7.5 \%)\left(G_{4}=25.33, P<\right.$ 0.001 ; Fig. 1). Cowbird parasitism in Black-capped Vireos varied among sites $\left(G_{5}=19.22, P\right.$ $=0.002$; Table 1 ). No vireo nests were found at Red Bluff in 1991. Only 1 vireo nest was found in 1992 and parasitism could not be determined; thus Red Bluff was not used in further analyses. Parasitism rates in other species were too low to determine differences among sites.

Removal of female cowbirds tended to reduce parasitism rates in Black-capped Vireos (Fig. 2), but the relationship was not significantly different than random, possibly due to small sample size. To be conservative, we removed effects of cowbird removal when testing for a relationship between host density and parasitism rate.

\section{HOST DENSITY}

Northern Cardinals were the most abundant bird on Fort Hood $(\bar{x} \pm$ SE, $1.09 \pm 0.07$ in 1991, $0.76 \pm 0.05$ in 1992, Fig. 3). In 1991, cumulative host density, cardinal and chat densities differed among sites, whereas bunting, Black-capped and White-eyed Vireo densities did not (Table 2, Fig. 3). In 1992, cumulative host density and densities of all species except White-eyed Vireo differed among sites (Table 2, Fig. 3).

Cumulative host density was correlated with parasitism rates of Black-capped Vireos and parasitism rates of all vireos when rate of female cowbird removal among sites was controlled (Fig. 4A). Parasitism rates were highest at those sites with the greatest cumulative density of hosts. However, parasitism rate in vireos was even more strongly correlated with cardinal den- 


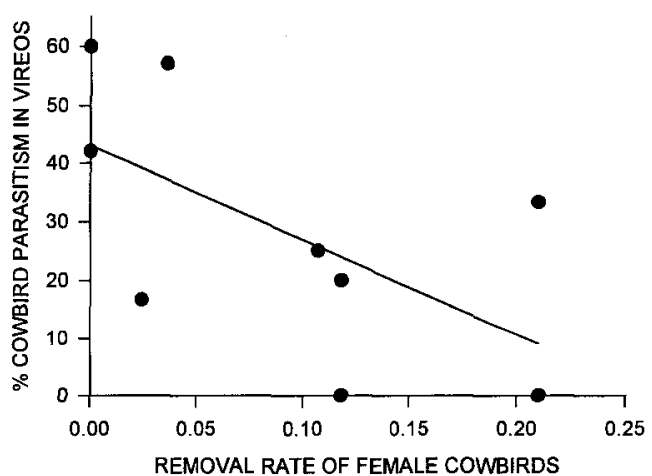

FIGURE 2. Relationship between Brown-headed Cowbird parasitism rate in Black-capped Vireos and removal rate of female cowbirds among study sites on Fort Hood, Texas in 1991 and 1992. Removal rate of female cowbirds is measured as the number of female cowbirds caught in traps per day. Equation for the fitted line is: parasitism rate $=-169.9$ (removal rate of female cowbirds) $+43.1 ; F_{1,8}=4.06, P=0.08, r=$ -0.61 .

sity alone after cowbird removal was controlled (Fig. 4B). In order to determine whether cowbirds were responding to cumulative host density or cardinal density, we separated cumulative host density into cardinal density and density of other species. Stepwise linear regression was used to force both cardinal density and density of other species into the model as the first variable. A significant bivariate correlation was found between cardinal density and parasitism rates $\left(r^{2}=0.94, P<0.001\right)$, whereas the correlation between density of other species and parasitism rate was not significant $\left(r^{2}=0.36, P\right.$ $=0.07)$. When both variables were in the model, the significance values for cardinals and the rest of the species were $P=0.001$ and $P=0.66$, respectively. Parasitism rates in Black-capped
Vireos were not correlated with density of Black-capped Vireos $\left(r_{\mathrm{p}}=0.31, P=0.51\right)$, White-eyed Vireos $\left(r_{\mathrm{p}}=0.60, P=0.16\right)$, chats $\left(r_{\mathrm{p}}=-0.24, P=0.61\right)$, or buntings $\left(r_{\mathrm{p}}=0.42\right.$, $P=0.35)$ after controlling for effects of cowbird removal.

\section{NEST SITE CHARACTERISTICS}

Due to small sample sizes, White-eyed Vireo nests are not included in analyses of nest site and nest vegetation characteristics among species. However, Black-capped and White-eyed Vireo nests did not differ in nest site characteristics, but differed in vegetation characteristics. White-eyed Vireos had more Texas oak saplings $(2-10 \mathrm{~cm} \mathrm{dbh})$ surrounding the nest than did Black-capped Vireos (Barber, unpubl. data). Vireo nests were placed farther away from the stem, and had less overhead cover and less side cover than other species (Table 3). Vireos nested in areas with greater canopy cover than other species. Moreover, vireo nests were placed lower in the vegetation than other species, although only significantly lower than cardinal nests (Table 3 ). Vireo nests also were surrounded by more saplings (dbh $2-10 \mathrm{~cm})$ and trees $(\mathrm{dbh}>10 \mathrm{~cm})$ than other species (Table 3 ). Nest and vegetation characteristics did not differ between parasitized and unparasitized vireo, chat, cardinal, or bunting nests.

\section{DISCUSSION}

Probability of cowbird parasitism for a species may be influenced by several factors. We tested two hypotheses: (1) cowbird parasitism rates in a single species are influenced by density of coexisting host species and (2) cowbird parasitism rates are influenced by nest-site characteristics and vegetation surrounding the nest.

TABLE 2. Mean \pm SE cumulative host density and results from Mann-Whitney $U$-tests for differences in host density between years 1991 and 1992 for six study sites on Fort Hood. Density was calculated as total number of individuals detected per census point.

\begin{tabular}{lccc}
\hline \multicolumn{1}{c}{ Site } & $1991^{\mathrm{a}}$ & $1992^{\mathrm{b}}$ & $P$ \\
\hline Area 2 top & $2.88 \pm 0.25$ & $1.70 \pm 0.22$ & $<0.001$ \\
Area 2 slope & $4.00 \pm 0.28$ & $3.03 \pm 0.23$ & 0.01 \\
Red Bluff & $3.28 \pm 0.25$ & $2.75 \pm 0.27$ & 0.19 \\
West Fort Hood & $3.68 \pm 0.25$ & $2.35 \pm 0.26$ & $<0.001$ \\
Manning Mountain & - & $2.80 \pm 0.22$ & - \\
Brown's Creek $^{\mathrm{c}}$ & - & $3.67 \pm 0.40$ & - \\
\hline
\end{tabular}

\footnotetext{
${ }^{a}$ Kruskal-Wallis test among sites in 1991: $x^{2}{ }_{3}=8.1, P=0.03$.

b Kruskal-Wallis test among sites in 1992: $\chi^{2}{ }_{5}=22.8, P<0.001$

c Site was not sampled during 1991.
} 

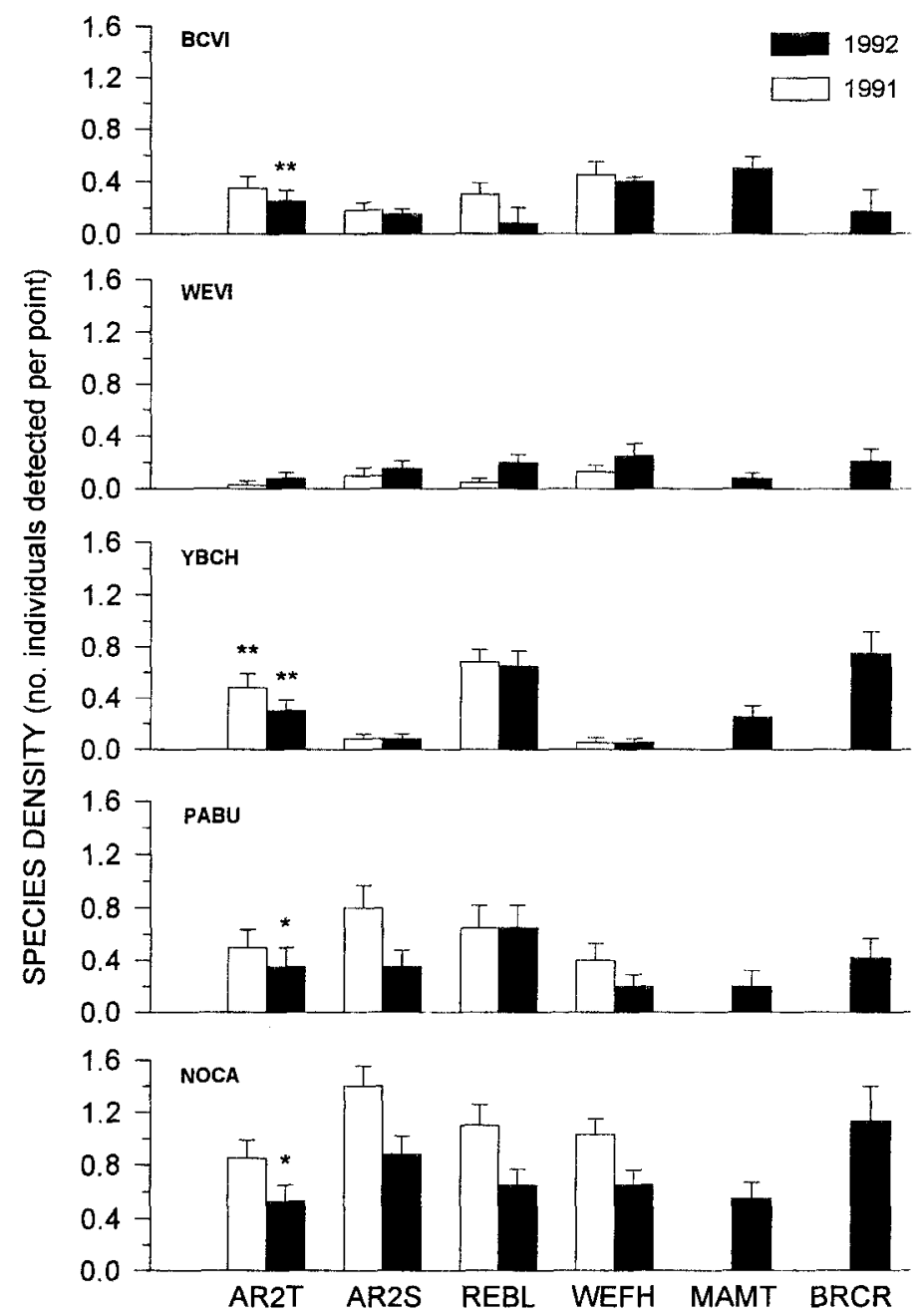

FIGURE 3. Mean density of Black-capped Vireos (BCVI), White-eyed Vireos (WEVI), Yellow-breasted Chats (YBCH), Painted Buntings (PABU), and Northern Cardinals (NOCA) in six study sites on Fort Hood, Texas, in 1991 and 1992. Vertical lines represent 1 SE. Densities of species are compared among sites for each year using a Kruskal-Wallis test, $* P<0.05, * * P<0.01$.

Cowbird parasitism of Black-capped Vireos was greater in areas with higher densities of potential hosts. Circumstantial evidence suggests that cowbirds respond to cumulative host density. Cowbird parasitism is greater at forest edges than in forest interiors (Brittingham and Temple 1983, Johnson and Temple 1990) following the pattern of bird density (Gates and Gysel 1978, Morgan and Gates 1982). Moreover, cowbirds have shown a positive density dependent response to cumulative host density in one study of open habitat (Lowther and Johnston 1977). Cumulative host density usually is not separated into density of individual species, so it is impossible to tell whether cowbirds are attracted to cumulative host density or density of particular species. Although parasitism rates were greatest in areas with the highest cumulative host density in our study, this relationship was driven by cardinal density; cowbird parasitism in Black-capped Vireos was greatest where cardinal density was highest, and the density of other coexisting species did not affect this relationship.

Why would cowbirds respond to cardinal density rather than cumulative host density? Female cowbirds may respond to host species that are 


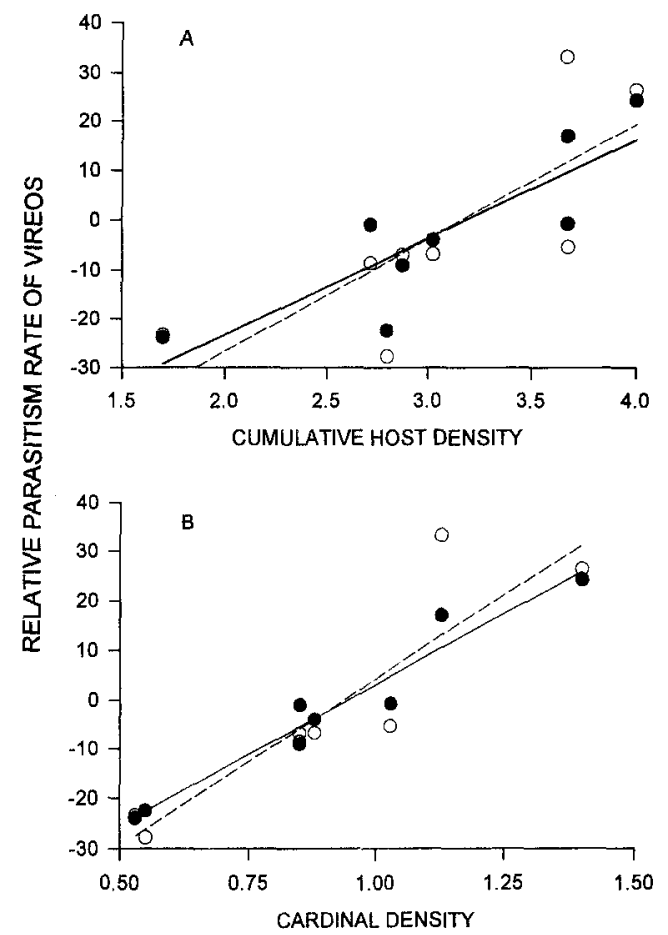

FIGURE 4. (A) Partial correlation of parasitism rates in Black-capped Vireos, all vireos and cumulative host density among study sites while controlling for removal of female cowbirds. Relative parasitism rate is the residuals from regression of female cowbird capture rate on parasitism rate. Relative parasitism rates are represented by closed and open circles for Black-capped and White-eyed Vireos, respectively. Cumulative host density is the number of birds of all host species per point count. Equation for the fitted solid line is: relative parasitism rate in Black-capped Vireos $=19.8$ (host density) $-62.9 ; F_{1,6}=15.58, P=0.008, r_{\mathrm{p}}=$ 0.85. Equation for the fitted dashed line is: relative parasitism rate in all vireos $=23.0$ (host density) 72.7; $F_{1.6}=9.00, P=0.024, r_{\mathrm{p}}=0.77$. (B) Partial correlation of parasitism rates in Black-capped Vireos, all vireo nests and Northern Cardinal density among study sites while controlling for removal of female cowbirds. Relative parasitism rates are represented by closed and open circles for Black-capped and Whiteeyed Vireos, respectively. Equation for the fitted solid line is: relative parasitism rate in Black-capped Vireos $=56.9$ (cardinal density) $-53.9 ; F_{1,6}=105.1, P<$ $0.001, r_{\mathrm{p}}=0.99$. Equation for the fitted dashed line is: relative parasitism rate in all vireos $=67.6$ (cardinal density) $-63.34 ; F_{1,6}=26.54, P=0.002, r_{\mathrm{p}}=0.92$.

particularly conspicuous, such as cardinals, which are bright red and sing loudly from the tops of the tallest trees. Such conspicuous species may provide an effective cue of areas for cowbirds to search for nests. If cowbirds use

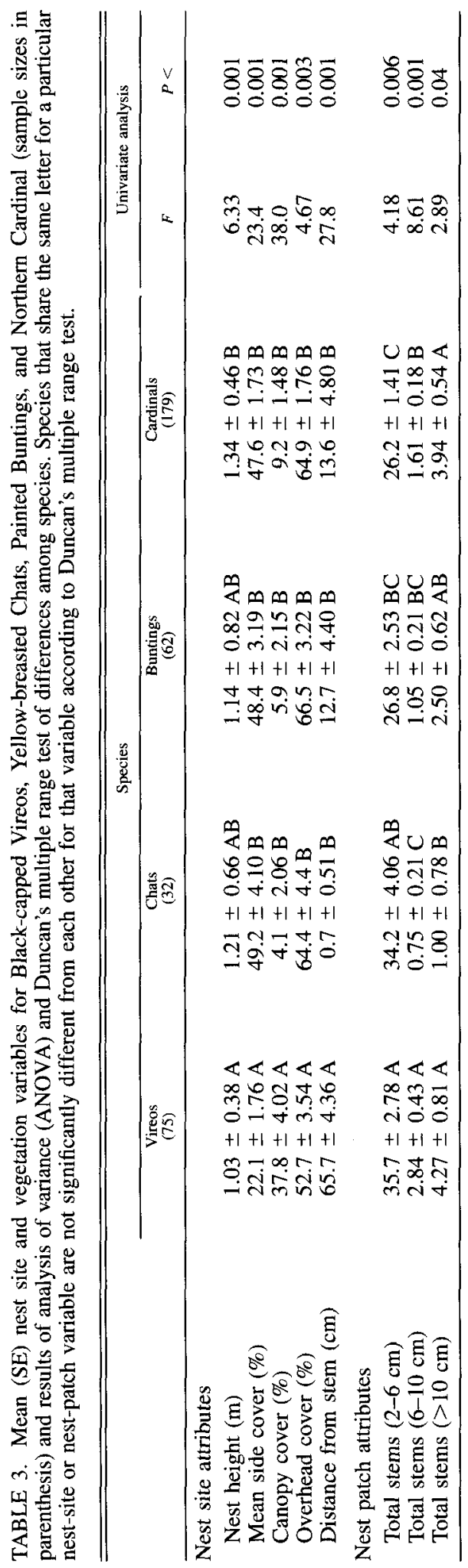


cardinal density as a cue, then cardinals may indirectly affect parasitism in Black-capped Vireos by attracting cowbirds. Of course, correlation does not imply causation. Experimental reduction of cardinal density among sites and measuring corresponding cowbird parasitism rates is needed to verify this relationship. Nonetheless, this correlation suggests that cowbirds may use conspicuous host species as a cue, and high densities of such species may increase probability of parasitism of coexisting host species.

Black-capped and White-eyed vireos suffered approximately three to four times higher parasitism than any other shrub-nesting species on Fort Hood, including cardinals. Why do vireos suffer higher parasitism rates than other species? Among coexisting species, the probability of a particular species being parasitized may be influenced by several factors: (1) nest concealment, (2) vegetation characteristics surrounding the nest, and (3) behavior. Vireos build pensile nests placed near the ends of branches (Bent 1965; this study). The result is less overhead and side cover (i.e., less nest concealment) than nests of other shrub nesting species (Table 3), which may make vireo nests more visible to cowbirds. Vireo nests also differed from other species' nests by having more saplings and trees surrounding the nest (Table 3 ), which may make them more susceptible to cowbird parasitism. Brown-headed Cowbirds may find nests by perching in the tops of trees and observing adults build nests (Norman and Robertson 1975, Thompson and Gottfried 1976, 1981, Lowther 1979). If vireos are more susceptible to parasitism due to less nest concealment and higher densities of trees, then we would expect parasitized vireo nests to have less nest concealment and more trees surrounding them than unparasitized vireo nests. However, similar to other studies (Best 1978, Smith 1981; but see DellaSala 1985), parasitized and unparasitized nests did not differ in either nest or vegetation characteristics. These results suggest that other characteristics of vireos may be responsible for their high parasitism rates.

Species in the genus Vireo all seem highly susceptible to cowbird parasitism (Southern 1958, Franzreb 1989, Marvil and Cruz 1989). Vireos may have more conspicuous behavior than other species. Male vireos share in nest building, often sit on eggs while the female is foraging, and sing from the nest (Bent 1965), which may make nests more conspicuous. Conspicuous behavior is associated with probability of parasitism; Willow Flycatcher pairs that were noisier around the nest were more likely to be parasitized than quiet pairs (Uyehara and Narins 1995).

Black-capped Vireos show no aggression towards cowbirds (D. Barber, pers. observ.). This lack of aggression may make vireos more susceptible to parasitism, especially if other host species show greater aggression towards cowbirds. Briskie et al. (1990) concluded that cowbirds preferentially parasitized Yellow Warblers over Least Flycatchers (Empidonax minimus) because flycatchers showed greater aggression when presented with a cowbird model. Cardinals are larger than cowbirds and may be able to defend their nest against cowbirds.

All nests in this study were found in the early successional habitat favored by Black-capped Vireos. Vireos typically chose nest sites with greater canopy cover and more saplings surrounding their nests than other shrub-nesting species (Table 3). Increased parasitism in vireos could reflect that cowbirds preferred to search for nests in habitats where vireos preferentially nested. Yet, unparasitized nests of other species, such as Cardinals and Yellow-breasted Chat, were often found within a couple of meters and interspersed with parasitized vireo nests. These unparasitized nests occurred in the same areas and habitats that cowbirds often frequented (D. Barber, pers. observ.). Moreover, vireos suffer high parasitism even in markedly different habitat, such as eastern deciduous forests (Southern 1958), suggesting vireos are simply highly vulnerable, regardless of habitat use (also see earlier).

Studies of endangered species threatened with cowbird parasitism have concentrated only on the endangered species and ignored coexisting species, despite the fact that Brown-headed Cowbirds are host generalists. Possible indirect effects of cardinal density on cowbird parasitism of vireos, suggested by correlations documented in this study, suggest that densities of coexisting species must be taken into account in studies of cowbird parasitism, or at the very least investigators must be aware of the effects of alternate host densities in the design of experiments and analysis of results. 


\section{ACKNOWLEDGMENTS}

We thank D. Adams, K. Breuner, T. Hayden, A. Knight, and especially D. House for finding and monitoring nests. J. Cornelius, T. Hayden, D. Herbert, and D. Tazik assisted in locating study areas, facilitated access, and helped coordinate field activities. We are grateful to P. Barber, J. Barlow, S. Garner, P. Martin, L. Petit, S. Rothstein, and an anonymous reviewer for constructive discussions and comments on earlier drafts of this manuscript. This study was supported by the Arkansas Cooperative Fish and Wildlife Research Unit and the U.S. Army Construction Engineering Research Lab, Champaign, Illinois.

\section{LITERATURE CITED}

Alvarez, F. 1993. Proximity of trees facilitates parasitism by Cuckoos Cuculus canorus on Rufous Warblers Cercotrichas galactotes. Ibis 135:331.

Anderson, W. L., And R. W. Storer. 1976. Factors influencing Kirtland's Warbler nesting success. Jack-Pine Warbler 54:105-115.

BENT, A. C. 1965. Life histories of North American wagtails, shrikes, vireos and their allies. Dover Publications, New York.

BEST, L. B. 1978. Field Sparrow reproductive success and nesting ecology. Auk 95:9-22.

Briskie, J. V., S. G. SEAly, ANd K. A. Hobson. 1990. Differential parasitism of Least Flycatchers and Yellow Warblers by the Brown-headed Cowbird. Behav. Ecol. Sociobiol. 27:403-410.

Brittingham, M. C., And S. A. Temple. 1983. Have cowbirds caused forest birds to decline? BioScience 33:31-35.

Brown, B. T. 1988. Breeding ecology of a Willow Flycatcher population in Grand Canyon, Arizona. West. Birds 19:25-33.

Clark, K. L., ANd R. J. Robertson. 1979. Spatial and temporal multi-species aggregations as anti-parasite and anti-predator defense. Behav. Ecol. Sociobiol. 5:359-371.

DellaSala, D. A. 1985. The Yellow Warbler in southeastern Michigan: factors affecting its productivity. Jack-Pine Warbler 63:52-60.

FrANZREB, K. E. 1989. Endangered status and strategies for protection of the Least Bell's Vireo (Vireo bellii pusillus) in California. West. Birds 18:4349.

Freeman, S., D. F. Gori, AND S. Rohwer. 1990. Red-winged Blackbirds and Brown-headed Cowbirds: some aspects of a host-parasite relationship. Condor 92:336-340.

Fretwell, S. D. 1977. Is the Dickcissel a threatened species? Am. Birds 31:923-932.

FrIEDMANN, H. 1963. Host relations of the parasitic cowbirds. U.S. Natl. Mus. Bull. 37:21-29.

FriedmanN, H., AND L. F. KIFF. 1985. The parasitic cowbirds and their hosts. Proc. West. Found. Vert. Zool. 2:225-302.

GATES, J. E., AND L. W. GySEl. 1978. Avian nest dispersion and fledgling success in field-forest ecotones. Ecology 59:871-883.

Goldwasser S., D. Gaines, and S. R. Wilbur. 1980.
The Least Bell's Vireo in California: a de facto endangered race. Am. Birds 34:742-745.

Graber, J. W. 1961. Distribution, habitat requirements and life history of the Black-capped Vireo (Vireo atricapilla). Ecol. Monogr. 31:313-336.

Gryzbowski, J. A., R. B. Clapp, and J. T. Marshall. 1986. History and current status of the Black-capped Vireo in Oklahoma. Am. Birds 34:742-745.

HolT, R. D. 1977. Predation, apparent competition and the structure of prey communities. Theor. Pop. Biol. 12:197-229.

Hutto, R. L., S. M. Pletschet, and P. Hendricks. 1986. A fixed-radius point count method for nonbreeding and breeding season use. Auk 103:593602.

Johnson, R. G., AND S. A. Temple. 1990. Nest predation and brood parasitism of tallgrass prairie birds. J. Wildl. Manage. 43:106-111.

LowTHER, P. E. 1979. Nest selection by Brown-headed Cowbirds. Wilson Bull. 91:118-122.

LOWTHER, P. E., AND R. F. JOHNSTON. 1977. Influences of habitat on cowbird host selection. Kansas Ornithol. Soc. Bull. 28:36-40.

Marshall, J. T., JR., R. B. Clapp, and J. A. GryZBOWSKI. 1985. Status report: Vireo atricapillus Woodhouse, Black-Capped Vireo. Rep., Office Endangered Species, U.S. Fish Wildl. Serv., Albuquerque, NM.

MarTin, T. E. 1988. On the advantage of being different: nest predation and coexistence of bird species. Proc. Natl. Acad. Sci. 85:2196-2199.

MarTin, T. E. 1992. Breeding productivity considerations: what are the appropriate habitat features for management?, p. 455-473. In J. Hagan III and D. W. Johnston [eds.], Ecology and conservation of Neotropical migrant landbirds. Smithson. Inst. Press, Washington, DC.

MARTIN, T. E. 1996. Fitness costs of resource overlap among coexisting bird species. Nature 380:338340.

Marvil, R. E., AND A. CRUZ. 1989. Impact of Brownheaded Cowbird parasitism on reproductive success of the Solitary Vireo. Auk 106:476-480.

MAY, R. M., AND S. K. Robinson. 1985. Population dynamics of avian brood parasitism. Am. Nat. 126:475-494.

MAYFiELD, H. 1977. Brown-headed Cowbird: agent of destruction? Am. Birds 31:107-113.

Morgan, K. A., And J. E. Gates. 1982. Bird population patterns in forest edge and strip vegetation at Remington Farms, Maryland. J. Wildl. Manage. 46:933-944.

Norman, R. F., and R. J. Robertson. 1975. Nest searching behavior in the Brown-headed Cowbird. Auk 92:610-611.

PAYne, R. B. 1977. The ecology of brood parasitism in birds. Annu. Rev. Ecol. Syst. 8:1-28.

RobINSON, S. K. 1992. Population dynamics of breeding Neotropical migrants in a fragmented Illinois landscape, p. 408-418. In J. Hagan III and D. W. Johnston [eds.], Ecology and conservation of Neotropical migrant landbirds. Smithson. Inst. Press, Washington, DC.

Robinson, S. K., AND D. S. Wilcove. 1994. Forest 
fragmentation in the temperate zone and its effects on migratory songbirds. Bird Conserv. Int. 4: 233-249.

RothSTeIN, S. I. 1975. An experimental and teleonomic investigation of avian brood parasitism. Condor 77:250-271.

SAS InSTitute. 1985. SAS/STAT user's guide. Release 6.0. SAS Institute, Inc. Cary, NC.

SchMIT, R. J. 1987. Indirect interactions between prey: apparent competition, predator aggregation and habitat segregation. Ecology 68:1887-1897.

SMiTH, J. N. M. 1981. Cowbird parasitism, host fitness, and age of the host female in an island Song Sparrow population. Condor 83:152-161.

SoutherN, W. E. 1958. Nesting of the Red-eyed Vireo in the Douglas Lake region, Michigan, part 2. Jack-Pine Warbler 36:185-207.

TAZIK, D. J., AND J. D. Cornelius. 1990. The Blackcapped Vireo on the lands of Fort Hood, Texas. Part III: population and nesting ecology. U.S.
Army Construction Eng. Res. Lab, Tech. Rep., Champaign, IL.

Tazik, D. J., J. D. Cornelius, C. A. Abrahamson, And V. E. HARMON. 1990. The Black-capped Vireo on the lands of Fort Hood, Texas. Part I: distribution and abundance. U.S. Army Construction Eng. Res. Lab, Tech. Rep., Champaign, IL.

Thompson, C. F., AND B. M. GotTFRIED. 1976. How do cowbirds find and select nests to parasitize? Wilson Bull. 88:673-675.

Thompson, C. F., AND B. M. GotTFried. 1981. Nest discovery and selection by Brown-headed Cowbirds. Condor 83:268-269.

UNITT, P. 1987. Empidonax trailii extimus: an endangered subspecies. West. Birds 18:137-162.

U.S. FISH AND WILDLIFE SERviCE. 1991. Black-capped Vireo (Vireo atricapillus) recovery plan. Austin, TX.

UyeHARA, J. C., AND P. M. NARRINS. 1995. Nest defense by Willow Flycatchers to brood-parasitic intruders. Condor 97:361-368. 